\title{
Importance of Incorporating Social Philosophical and Non-Material Cultural Aspects into Disaster Management Initiatives: The Case of Covid-19 Epidemic in Sri Lanka
}

\author{
A.G. Amarasinghe \\ Department of Geography, University of Kelaniya \\ DOI: 10.29322/IJSRP.10.11.2020.p10705 \\ http://dx.doi.org/10.29322/IJSRP.10.11.2020.p10705
}

\begin{abstract}
COVID-19 originated in Wuhan, China spreads around the world from December 2019 kills hundreds of people in a country and thousands daily collapsing all kind of local and international human activities.

Sri Lankan societies evolve from oldest civilization, consist with multi-cultural societies and sustained with traditional socioeconomic basement. "Dewey's Theory of Social Conflict" explains that societies with primitive features are vulnerable during large scale disastrous situation to immerge conflicts and disputes. Such conflicts can be averted by using potentials of nonmaterial cultural values blended with Social Philosophy.

Aim of this study was to identify the importance of social philosophical and non- material cultural aspects in managing disasters. Qualitative data is the main type of data. As this research conducted during the "stay at home order" reviewing literature through browsing web pages, making telephone conversation, inspection social media, observations and making inquiries were the method applied to collect data. Raw data were analyzed using related to conceptual and content analysis methods.

Results of this study reveal that consideration the main components of the non-material culture has become an urgent requirement in disaster management process. More attention should be paid on central integrals of religion, norms, values, witches, witchcrafts and magic that consisted with non-material culture. Therefore, mediation of social philosophers can be recognized as a crucial importance in finding ways and means to reduce impacts of natural and man-made disasters particularly in the countries with primitive cultural characteristics.
\end{abstract}

Key Words: COVID 19, Non-material culture, social philosophy, disaster management,

\section{Introduction}

The "Severe Acute Respiratory Syndrome Coronavirus 2" (SARS-CoV-2) or New Corona Virus Disease (COVID-19) originated in Wuhan, a city in the Hubei Province, China and spread around the world within four months from December 2019. This kind of disaster hit world widely after "Spanish Flu", spread during 1918 -1920. Number of affected people was 500 million around the globe and one-fifth of them died . (Jarus, O, 2020).

COVID-19 kills hundreds of people in a country and thousands of people from the world within daily collapsing all kind of local and international human activities. This disease shocked the general public around the world disrespecting any divisions and matured as a disaster within short period of time. Therefore, World Health Organization (WHO) designated the COVID-19 as a "pandemic" on 11, March 2020 urging international community to take immediate action to control this endemic. By $12^{\text {th }}$ April 2020 , total number of infected persons around the globe is $1,776,157$ and death toll is 108,804 . Total number of people recovered from this disease is 402,903 (CSSE, 2020).

Total number of covid-19 infected people and deaths per day is escalating at an alarming rate in advanced countries amidst all facets of development. This situation affects negatively to developing countries like Sri Lanka having a notion of more vulnerable 
to COVID-19 than developed countries. Therefore, medical practitioners other responsible and accountable officers and leaders urge government of Sri Lanka to take immediate action to control spreading this pandemic. It is a significant fact that the government of Sri Lanka respects the demand of government officers, advices of World Health Organization (WHO) and information of international mass media at this crucial juncture other than previous regimes. Closing schools and universities, imposing curfew, establishing quarantine centers, closing airport and make aware general public intensively about the horrifying nature of the COVID-19 were the main action taken by the government and relevant institutions. Other than these initiatives few "Presidential task forces" were established to cater with the epidemic and to maintain the day to day life of the general public. Police department and three forces, Director General of Health and other officers provide information and guidelines constantly. People are advised to be strict with the law and order. All these efforts seem to be help in controlling COVID 19 successfully in Sri Lanka.

Even then, getting bulk of local and international horror news coincides with immediate and sudden actions along with restrictions created array of problems throughout the country. These problems appear as social, psychological, economic, and political issues. At the same time, general public was disgusted, shocked and find faults of others. Further, they try to find solutions not only to this pandemic but also to other issues emerged around the sudden change of the socio-economic and political spheres.

The noticeable fact is the behavior of the general public has changed significantly after invading COVID-19 Sri Lanka. Going behind myths, incline to use spiritual powers, expecting healings from rituals can be seen as strategies applied by the general public to find solution for this obstacle. Surfacing old ideologies, concepts and theories are used to provide explain the causes and effects of this epidemic. Many try to find personalities who should responsible and accountable for this disaster. There are positive and negative results of this situation. One facet of this phenomenon is labeling politicians, religious doctrines, religious leaders, cultures and social groups as the accused of spreading this virus around the country. On the other hand, many people act against the law and order, ethics and cultural values. It seems that all these impacts relating to COVID-19 are the products of social philosophical and non-material cultural elements and aspects.

It is obvious that as COVID-19 hits, social philosophical and non-material cultural elements surface actively throughout every segment in Sri Lankan societies. This is because these societies evolve from oldest civilization of the world history. Further, Sri Lanka consists with multi-cultural, multi-religious and multi facets societies. At the same time, this country is still sustained with traditional and ancient socio-economic basement. Therefore, primitive features are more in the social and cultural aspects in this country than the Western world. According to the "Dewey's Theory of Social Conflict", this kind of social features and diversity may easily lead to create conflict and disputes among different groups of people (Frega, 2015, Robinson, N., 2016). However, such types of conflict can be averted by using potentials of non- material cultural values [5] (Nonmaterial Culture: Definition, Components \& Examples, 2015).

Harvesting benefits from non-material culture of Sri Lanka has become an urgent requirement at present. Therefore, this situation should be taken into consideration as needed by the planners and policymakers. Disregarding this situation linked with social philosophical and non-material cultural aspects can easily act as a hazard which may realize as catastrophe in near future. The impact of such devastation may be greater than Tsunami-2004 or COVID-19. Effects of such disaster can be minimized through making aware the vulnerable community about disaster risk management strategies (Shawiah, F.F.S.B., 2016, Inonye, J. 2014, Outreville, J. 1998 and Arnold et all, 2018). This includes understanding of disaster risk in all its dimensions of vulnerability, capacity, exposure of persons and assets, hazard characteristics and the environment. Such knowledge can be used for risk 
assessment, prevention, mitigation, preparedness and response [9] (UNDRR,2015). Ministry of Disaster Management of Sri Lanka initiated numerous programs to manage impacts of disasters for over 16 years. Yet, the involvement of general public in managing the impacts of COVI-19 epidemic is not in satisfactory level. One of main reason for this might be the disregarding the potentials of metaphysical values inherited with Sri Lanka.

Sri Lanka Disaster Management Act, No 13 of 2005 had paved the way to established three intuitions namely Ministry of Disaster Management, National Council for Disaster Management and Disaster Management Centre. The overall objective of this act is protect human life and property of the people and the environment of Sri Lanka from the consequence of these disasters, by effectively dealing with them from a national perspective by the preparation of a national policy and a plan and by the appointment of centrally co-ordinated committees and institutions to give effect to such policy and plans. These establishments can be directed to explore the ways and means to streamline the values of metaphysical and non-material cultural aspects of Sri Lankan social groups into manage disasters such as COVID-19 successfully.

\section{Social Philosophy and Non-Material Culture and Their Aspects}

"Social philosophy" is one of the main branches of the subject of philosophy. "Non- material culture" is a core and first order concept of the social sciences such as sociology and anthropology.

There are numerous introductions and definitions in the literature given to explain the scope and functions of social philosophy. When analyzing them, it can simply be concluded that social philosophy deals with concepts discussed and developed in the subject field of social sciences. Social sciences some time named as art subjects are divided into main two subject areas in Sri Lanka as social science and humanities. Main subjects that engage with core social functions and issues in these fields are geography, sociology, history, archeology, economics, and political science. Subject streams dealing with religions, fine arts, languages, mass communication, disaster management etc. are also recently developed subjects within the field of social sciences.

According to prominent philosopher Harry Allen Overstreet (1914), main objective of the social philosophy is inspection of concepts more penetratingly given by social scientists. As the subject areas of all subjects in social sciences are organized and controlled by the curricular, academics and respective scholars do not have a room to pay attention on all facets of respective concepts. Therefore, metaphysical aspects, moral and ethical questions have to be kept aside. For example, concepts on soil, rocks and water are discussed in the subject of geography. Yet social value of them and ethical responsibility of conserving them are vaguely or not taking into consideration by the geographers. Therefore, acquiring extensive knowledge and averting moral questions on soil, rocks and mineral by the respective scholars do not help to conserve and to practice to sustainable use of these resources. In such situations, social philosophers can mediate to develop new concepts or strategies to solve mistreated issues and adduced reasons by the social scientists (Robinson, N, 2016).

In order to ensure the utilization of social power positively and averting social conflict social philosophers such as Frega, (2015) Overstreet (1914), and Robinson (2016) urges to make philosophical inquiry over the concepts dealt with the social sciences. This initiative paves the way to make metaphysical and logical inquiries interpretation comprehensively and critically on social issues. Such drive services to understand the real and authentic moves relevant to contemporary social powers. Knowledge on the behavior of social power would help to recognize suitable and appropriate "social control measures" that can be utilized in a disastrous situation like COVID-19, to reduce the impacts of such epidemic. Therefore, it can be accepted that the concept of "Non- material culture" comes directly under the purview of social philosophy. 
The concept "Non- material culture" is defined as the rules and standards of society that circumscribe individual action through the inculcation of conventional sanctions and the imposition of formalized mechanisms ("Social control", 2020). There are seven components of nonmaterial culture (Study.com, 2020). They are gestures, language, values, norms, sanctions, folkways, and mores. These components are interconnected and shape by religion, belief system, myths and other metaphysical aspects of the social groups, social power or culture. Researchers have found out that culture influences directly to disaster risk reduction initiatives (Kulathunga,U. 2010, Kyoo-Man Ha, 2015). This shows that many have found the influence of non- material cultural aspect in to the disaster management process similar to the legal system in a country.

\section{Aims of the Research}

Main aim of this study is to identify the importance of social philosophical and non- material cultural aspects in managing the disasters such as OCVID 19. Secondary objectives of the current study are to trace laps and gaps of the behavior of among individuals and social groups in Sri Lanka. Fulfilling these objectives would pave the path for a revision of the concepts of disaster management.

\section{Methods and materials}

Qualitative data are main type of data used in this study. Reviewing literature through library survey and web pages browsing were the main method that used to collect data. Both published pear reviewed journal articles, online encyclopedias, distortionary were the main sources of information of the study. As this article compiled during the COVID 19 induced "stay at home" order, Telephone conversation were made with due academics to get clarification and further information over the concerned matters. Official information on the impacts and the disaster management process in Sri Lanka and other countries were collected through reputed television channels. Social media such as Face Book (FB) and information from general public contacted were used to collect relevant information. Observations and inquiries made to verify he collected data. Collected data were analyzed using methods related to conceptual analysis and content analysis.

Though this study based on contemporary actual ground trough phenomenon, references for them did not included into this paper in order to reduce the length of the list of reference.

\section{Result and discussions}

Behavior of the general public during the COVID 19 controlling period which are closely related with "non- material culture" in Sri Lanka can be divided into two as positive and negative. Factors that influenced for such behavior can be analyzed with the help of concepts and theories relevant to Social Philosophy. It is obvious that metaphysical elements of individuals and social groups are surfacing remarkably as social behavior explained by the concepts relevant to "social philosophy" and "non-material culture" in Sri Lanka parallel to the consequences of the contemporary COVID-19 pandemic. These significant acts of people were taken into consideration in this study.

Since the behavior of people is a mixed influence of the socio-cultural and political background, it is difficult to categorized social behavior according to the components of non-material culture. Therefore, findings of this study were divided into six groups as;

1. Religious Behavior and folkways of general public

2. Moral, ethical behavior and social values of general public

3. Reemerging traditional gestures and taboo of general public

4. Myths banquet among general public

5. Immoral behavior committed against the advises of government 
6. Immoral and unethical behavior of people committed during the period of curfew (stay at home order)

All these behavior of few individuals or members of social groups has influenced by the actions taken by the government as measures to control the spread of COVID 19 in Sri Lanka. Among these six categories first three can be regarded as positive social appetites. Examples of these three are as in table 1,2 and 3 given below. Tables 4, 5 and 6 provide the negative traits of people that could be identified during the COVID 19 nitrous situation in this country. All these positive and negative characteristics of the behavior of general public are not previously crafted by any organized program or a social power. All these are just culminate and emerge from natural evolvement of the socio-economic and political background.

Buddhist monks had organized "pirith" chanting ceremonies in all temples all over the country. Some individuals, institutes and group of people distributed food rational for free of charge. Islam devotes requested from the government not to cremate and bury the remains of the Islam devotees who died from COVID-19 infections. There are arguments for and against over the government commitment of controlling this pandemic. Ayurvedic doctors prescribed indigenous medicine to prevent from COVID-19. Whether, these practices are good or bad, right or wrong general public in Sri Lanka are involving actively over these opinions and activities. This shows that there huge potential and enthusiasm among social groups discussed in the Social Philosophical theories and non-material cultural concepts. This kind of metaphysical values can be incorporated to harvest benefits from the established disaster management initiatives of Sri Lanka.

\section{Conclusion}

Results of this study shows that, there are enormous strengths, possibilities and potentials imbedded into the culture of Sri Lankan society which can be used to reduce impacts of disasters. The important fact is to harvest these benefits from existing non- material cultural aspects can be employed as a drive without investing huge bulk of money or other resources. On the other hand, if the respective parties ignore the negative traits of the general public that surfaced during disastrous situation, repercussion would be beyond the coping capacity of Sri Lanka. Therefore, it has become an urgent and important requirement for taking into consideration the main components of the non-material culture in the whole process of disaster management process. At this point, attention should be paid on central integrals of religion, norms, values, witches, witchcrafts and magic (white and black) that consisted with non-material culture.

Inspecting and inquiring nan-material cultures which craft the social powers, social controls and belief systems concentrated around magic through the light of Social Philosophical point of view critically would help to manage disasters satisfactorily. This will reciprocally create smooth path to gain economic development as well as social development of the country.

Social development helps to maintain the "social powers". Negative appetites of social groups cannot be controlled only by just available and out dated laws and "social control measures" in a multi-cultural and multi-faceted country like Sri Lanka. Many components relating to social control measures are very old or not revised according to contemporary socio-economic changes. Therefore, social philosophers should mediate at this juncture to find ways and means to solve coming social issues relating to both natural and man-made disasters.

\section{Acknowledgment}

Several scholars help me to carry out this study. Suggestions and clarifications made over the concepts and central theme of this article through telephone conversation and passing emails. I grateful to thank Senior Prof. Gamini Hapuarrachchi, Senior Prof. Department of Philosophy and Dr. Ubesekeara Dissanayake, Senior Lecturer, Head, Department of Sociology of the University of Kelaniya, Sri Lanka for their valuable encouraging support to given. 


\begin{tabular}{|c|c|c|}
\hline \multicolumn{3}{|c|}{$\begin{array}{c}\text { Religious Behavior and Folkways of General Public of Sri Lanka } \\
\text { During the COVID-19 Disastrous Situation }\end{array}$} \\
\hline \multicolumn{3}{|c|}{$\begin{array}{c}\text { Main and miner Activities Perform by General Public to Showcase the Acts of Generosity and } \\
\text { Spiritual Power }\end{array}$} \\
\hline & \multirow{6}{*}{$\begin{array}{l}\text { Conducting } \\
\text { religious activities } \\
\text { in order to get } \\
\text { spiritual power }\end{array}$} & Chanting "Pirith"* \\
\hline & & Preaching religious talks (Bana Deshana) \\
\hline & & Arms giving ceremonies \\
\hline & & Chanting in Christian churches and \\
\hline & & Chanting in Hindu Covils (Temples) \\
\hline & & Chanting in Muslim (Islam) churches \\
\hline \multirow{10}{*}{2} & \multirow{10}{*}{$\begin{array}{l}\text { Committing rituals } \\
\text { for healing and } \\
\text { appealing from God }\end{array}$} & Spending devotional life \\
\hline & & Worshiping Gods \\
\hline & & Devote valuable belongings to God \\
\hline & & Worshiping and venerating "Bo tree" \\
\hline & & $\begin{array}{l}\text { Reserving valuables for Gods to end this epidemic as soon as } \\
\text { possible }\end{array}$ \\
\hline & & Lighting oil laps - "pahan” \\
\hline & & Offering gifts for Gods \\
\hline & & $\begin{array}{l}\text { Promising to offer sacrifice in front of the sacred places, such as } \\
\text { shrine rooms of Load Buddha and different kinds of Gods, Buddhist } \\
\text { dagabase and devalayas }\end{array}$ \\
\hline & & $\begin{array}{l}\text { Promising to offer sacrifice in front of the sacred things places such } \\
\text { as sacred trees, statues of Lord Buddha and Gods. }\end{array}$ \\
\hline & & Worshiping artifact made in ancient or modern times \\
\hline \multicolumn{3}{|c|}{$\begin{array}{c}\text { (Table 02) } \\
\begin{array}{c}\text { Moral, Ethical Behavior Social Values of General Public of Sri Lanka } \\
\text { During the COVID-19 Disastrous Situation }\end{array}\end{array}$} \\
\hline \multicolumn{3}{|c|}{$\begin{array}{l}\text { Main and miner humanistic activities perform by general public to showcase the acts of generosity and } \\
\text { spiritual power }\end{array}$} \\
\hline 1 & \multicolumn{2}{|c|}{ Offering dry rations for free of charge to vulnerable families and persons } \\
\hline 2 & \multicolumn{2}{|c|}{$\begin{array}{l}\text { Contribution personal money for funds established by the government for COVID } 19 \text { pandemic } \\
\text { controlling program }\end{array}$} \\
\hline 3 & \multicolumn{2}{|c|}{ Educating general public over the safety measures } \\
\hline 4 & \multicolumn{2}{|c|}{ Participating requested program voluntarily by the government } \\
\hline 5 & \multicolumn{2}{|c|}{ Providing needed information to government enthusiastically } \\
\hline 6 & \multicolumn{2}{|c|}{ Initiating and carrying out essential and urgent activities voluntarily } \\
\hline 7 & \multicolumn{2}{|c|}{ Taking life threatening risks when needed } \\
\hline 8 & \multicolumn{2}{|c|}{ Finding and inquiring about difficulties faced by even unknown people } \\
\hline 9 & \multirow{2}{*}{\multicolumn{2}{|c|}{$\begin{array}{l}\text { Compelling to produce urgent and vital clinical equipment and machines and offer them freely. } \\
\text { Adhering to health and other official advices willingly and devotedly }\end{array}$}} \\
\hline 1 & & \\
\hline
\end{tabular}

\begin{tabular}{|l|l|l|}
\hline \multicolumn{2}{|c|}{$\begin{array}{l}\text { (Table 03) } \\
\text { Reemerging Traditional Gestures and taboo of General Public of Sri Lanka } \\
\text { During the COVID-19 Disastrous Situation }\end{array}$} \\
\hline \multicolumn{2}{|c|}{ Greetings* } & $\begin{array}{l}\text { Sinhalese say the word "Ayubowan" after palms } \\
\text { clasping together as if in prayer at chin level with a } \\
\text { slight nod of the head. "Ayubowan" means you be } \\
\text { blessed with a long life }\end{array}$ \\
$\begin{array}{l}\text { Tamil say the word "vanakam." means you be blessed } \\
\text { with a long life. (This is recognized as a most } \\
\text { important way of greeting to prevent from infecting } \\
\text { COVID-19) }\end{array}$ \\
\hline Quarantine
\end{tabular}




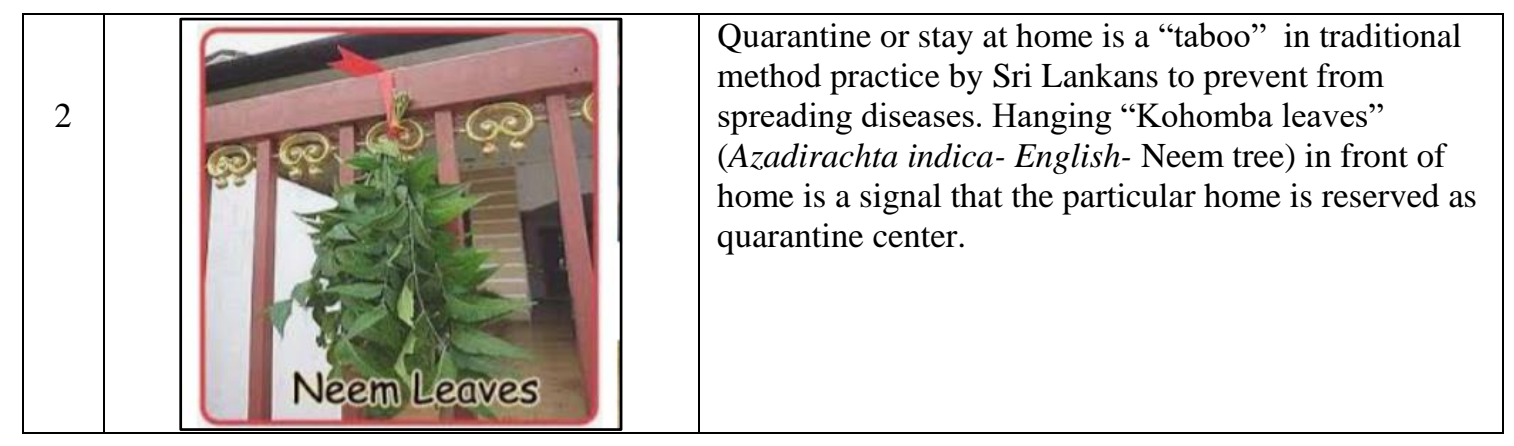

\begin{tabular}{|c|c|c|}
\hline \multicolumn{3}{|c|}{$\begin{array}{c}\text { (Table 04) } \\
\text { Myths Banquet Among General Public Over COVID } 19 \text { Pandemic } \\
\text { In Sri Lanka }\end{array}$} \\
\hline & Main Category & Fine points \\
\hline \multirow[t]{2}{*}{1} & \multirow{2}{*}{$\begin{array}{l}\text { Nature of } \\
\text { coronavirus }\end{array}$} & Most dangerous virus ever develop in the world \\
\hline & & Affect only to physically weak people \\
\hline \multirow[b]{2}{*}{2} & \multirow[b]{2}{*}{ Reasons for origin } & $\begin{array}{l}\text { God that controlled the earth is displeased with the people who do bad, } \\
\text { brutal and unethical and act to punish them }\end{array}$ \\
\hline & & $\begin{array}{l}\text { Reacting environment against the human activities that led to create } \\
\text { environmental problem }\end{array}$ \\
\hline \multirow{6}{*}{3} & \multirow{6}{*}{ Origin from } & From eating cats and dogs \\
\hline & & From having soup of bats \\
\hline & & From polluted environment \\
\hline & & Deliberately created and released \\
\hline & & Side effect of testing a weapon \\
\hline & & Recurrence/reappearance of a virus that has a 100 year cycle \\
\hline \multirow{3}{*}{4} & \multirow{3}{*}{ Infect only for } & Elders \\
\hline & & Weak persons \\
\hline & & Cursed people \\
\hline \multirow{5}{*}{5} & \multirow{5}{*}{$\begin{array}{l}\text { Protecting from } \\
\text { infection }\end{array}$} & Wearing mask would protect from infecting the virus \\
\hline & & Closed down infected areas completely \\
\hline & & Washing hand with soap is adequate \\
\hline & & Using and spray is enough \\
\hline & & Living in hot area with climate -tropical region \\
\hline \multirow{7}{*}{6} & \multirow{7}{*}{$\begin{array}{l}\text { Things to take as } \\
\text { medicine }\end{array}$} & Eating garlic and drinking water \\
\hline & & Antibiotics help to prevent the virus \\
\hline & & Drinking hot water six times per day flush the virus \\
\hline & & Rinse mouth with salt water will remove the virus \\
\hline & & Gargling bleach \\
\hline & & Inhaling evaporates of warm water thrice a day \\
\hline & & Having extra amount of alcohol/ liquor \\
\hline
\end{tabular}

\begin{tabular}{|c|c|}
\hline \multicolumn{2}{|l|}{$\begin{array}{c}\text { (Table 05) } \\
\text { Immoral Behavior committed Against the Advises of Government Given to Protect from } \\
\text { COVID-19 }\end{array}$} \\
\hline Main and miner misbehavior of general public that showcase the acts of not adhering to advice given \\
by the government to.
\end{tabular}




\begin{tabular}{|c|c|c|}
\hline \multirow[t]{3}{*}{1} & \multirow[t]{3}{*}{ infecting the virus } & Use of masks incorrectly \\
\hline & & Not using glows and other protection gears \\
\hline & & Not washing hands as needed \\
\hline \multirow{6}{*}{2} & \multirow{6}{*}{$\begin{array}{l}\text { Not refrain from } \\
\text { spreading the } \\
\text { pandemic }\end{array}$} & Escape/ elope from quarantine centers \\
\hline & & Hiding purposely after suffering from COVID 19 \\
\hline & & Loitering here and there hiding information \\
\hline & & Going to public places without keeping social distance \\
\hline & & Hiding symptoms and due information \\
\hline & & Refrain from undergoing given medical treatments \\
\hline \multirow{6}{*}{3} & \multirow{6}{*}{$\begin{array}{l}\text { Violating rules and } \\
\text { regulations or law } \\
\text { and order imposed } \\
\text { (as curfew) to } \\
\text { control } \\
\text { COVID } 19\end{array}$} & Open shops and selling goods \\
\hline & & Selling goods for excess price charging high prices \\
\hline & & Going for shopping \\
\hline & & Driving vehicle along main roads \\
\hline & & Organizing parties \\
\hline & & $\begin{array}{l}\text { Producing alcohol/ sprits illegally, transporting them and selling } \\
\text { secretly }\end{array}$ \\
\hline
\end{tabular}

\begin{tabular}{|c|c|c|}
\hline \multicolumn{3}{|c|}{$\begin{array}{l}\text { Immoral and unethical } \begin{array}{c}\text { Behavior of few people Committed during the curfew imposed (stay at } \\
\text { home order) to Protect from COVID-19 }\end{array} \\
\text { hom }\end{array}$} \\
\hline \multicolumn{3}{|c|}{$\begin{array}{l}\text { Main and miner misbehavior of few people among general public that showcase the acts of not } \\
\text { accepted by the Sri Lankans. }\end{array}$} \\
\hline \multirow[b]{3}{*}{1} & \multirow{3}{*}{$\begin{array}{l}\text { Stealing } \\
\text { Shoplifting } \\
\text { Burglary } \\
\text { Smuggling }\end{array}$} & Stealing taking grants from curfew \\
\hline & & Break in shops and stealing- specially liquor and medicine \\
\hline & & Looting money from government officers who were in the field \\
\hline \multirow{7}{*}{2} & \multirow{7}{*}{$\begin{array}{l}\text { Committing } \\
\text { illegal and } \\
\text { unethical } \\
\text { activities }\end{array}$} & Mining treasure, gem, sand.. \\
\hline & & Participating for illegal games- card playing \\
\hline & & Producing alcohol using primitive methods \\
\hline & & Shooting down wild animal to get flesh \\
\hline & & Killing domestic animals for food \\
\hline & & Use of social media (FB) to arouse general public \\
\hline & & Throwing kerosene oil into the heap of vegetable \\
\hline 3 & $\begin{array}{l}\text { Domestic } \\
\text { violence }\end{array}$ & $\begin{array}{l}\text { Quarreling among family members as a side effect of stress developed as } \\
\text { results of being at home long period of time }\end{array}$ \\
\hline
\end{tabular}

\section{List of Reference}

Arnolda, S.A., Brockdorffa ,N., Jakovljevb , I., Zdravkovićb, S, 2018, “Applying cultural values to encourage disaster preparedness: Lessons from a low-hazard country “, International Journal of Disaster Risk Reduction journal homepage: www.elsevier.com/locate/ijdrr, (Accessed 5 Apr. 2020)

CSSE, 2020, “Coronavirus COVID- 19 Global Cases” Center of Systems Science and Engineering. https://coronavirus.jhu.edu/map.html, 9accessed 12 Apr. 2020).

Frega Roberto, 2015, « John Dewey’s Social Philosophy », European Journal of Pragmatism and American Philosophy [Online], VII-2 | 2015, http://journals. openedition.org/ejpap/410; DOI: https://doi.org /10.4000/ejpap.410 (accessed 10 Apr. 2020)

Inonye, J. 2014, Risk Perception: Theories, Strategies, and Next Steps. National Safety Council, Campbell Institute, Campbellinstitute.org (accessed 11 Apr. 2020)

Jarus, Owen, 2020. 20 of the worst epidemics and pandemics in history All About History 15 days ago. https://www.livescience.com/worst-epidemics-and-pandemics-in-history.html (accessed 5 Apr. 2020).

Kulatunga, U, 2010, Impact of culture towards disaster risk reduction, International Journal of Strategic Property Management . December, 2010, https://www. researchgate.net/ publication/227640419 (accessed 5 Apr. 2020)

Kyoo-Man Ha, 2015, The Role of Religious Beliefs and Institutions in Disaster Management: A Case Study, religions ISSN 2077-1444 www.mdpi.com /journal /religions , https://www.researchgate.net/c _ (accessed 5 Apr. 2020) 
Nonmaterial Culture: Definition, Components \& Examples." Study.com, 18 August 2015, study.com/academy/lesson/nonmaterial-culture-definition-components-examples.html (accessed 6 Apr. 2020)

Outreville, J. François, 1998, Risk Management Concepts, https://www.researchgate.net/publication/ 302305569 Risk Management Concepts Chapter · January 1998 (accessed 5 Apr. 2020)

Overstreet, Harry, Allen, 1914, The Function and Scope of Social Philosophy, The Journal of Philosophy, Psychology and Scientific Methods, Vol. 11, No. 20 (Sep. 24, 1914), pp. 533-543 (11 pages), Journal of Philosophy, Inc., (accessed 8 Apr. 2020)

Robinson, N, 2016, The Necessity of Social Philosophy, available at SSRN: https://ssrn.com Robinson, Nathan, 2016, The Necessity of Social Philosophy, available at abstract=2847526 or http://dx.doi.org/10.2139/ssrn.2847526 ( accessed 10 Apr. 2020)

Shawiah, F.B.S.B. 1916, Risk Management Strategies for dealing with Unpredictable Risk in Saudi Arabian Organization, College of Science \& Technology School of the Built Environment, http://usir.salford.ac.uk /id/eprint/ 41318/3/C_Users_PVP994_Desktop_Faisal_Thesis_Corrected.pdf (accessed 9 Apr. 2020)

Social control.2020, "Social Control”, Merriam-Webster.com Dictionary, Merriam-Webster, https://www.merriamwebster.com/dictionary/ social\%20control (accessed 7 Apr. 2020).

Study.com, 2020, Definition of Non-Material Culture, https://study.com/academy/ lesson/nonmaterial-culture-definitioncomponents-examples.html (accessed 8 Apr. 2020)

UNISDR, 2015, “Sendai Framework for Disaster Risk Reduction, 2015 -2030”, 9-11, Rue de Verembe, CH 1202, Geneva, Switzerland. www.unisdr.org. (accessed 8 Apr. 2020) 